\title{
Academic supervision in improving teachers' professional competency in paramount school palembang
}

\author{
Kgs Rachmad Dody Fadillah ${ }^{1}$, Happy Fitria ${ }^{2}$, Alfroki Martha ${ }^{3}$ \\ ${ }^{1}$ SD Paramount Palembang \\ ${ }^{2}$ Universitas PGRI Palembang
}

\begin{tabular}{l} 
Article Info \\
\hline Article history: \\
Received Jul $12^{\text {th }}, 2021$ \\
Revised Aug $15^{\text {th }}, 2021$ \\
Accepted Aug $30^{\text {th }}, 2021$ \\
\hline
\end{tabular}

\section{Keyword:}

Academic Supervision

Principal,

Professional Competence

\begin{abstract}
The research problem is about the implementation of academic supervision held by the Paramount Primary School Principal which considered unoptimal. The aim of this study are: (1) Explaining the elements that being focused in academic supervision of Paramount Primary School. (2) Explaining the strategy of the Principal in improving teacher's professional competency. (3) Explaining the implementation of academic supervision held by the Principal (4). Analyzing the implementation of academic supervision held by the Principal in pandemic time. This reseach is a qualitatif descritive reseach, data collection technique used is participatory observation, in-depth interviews, and documentation. The subject in this study are the principal, teachers and students. The results of this study are: (1) the elements supervised, (2) Strategy applied in improving the professional competence of teachers and (3) The follow up conducted by the principal after the academic supervision activity.
\end{abstract}

\section{Corresponding Author:}

Kgs Rachmad Dody Fadillah

SD Paramount Palembang

Email: rd.paramountteacher@gmail.com

\section{Introduction}

The impact of the Covid 19 pandemic which has hit the entire world has given a big impact on all sectors of people's lives. One of the sectors affected is the education sector. This impact is perceived by teachers and students who are required to carry out learning from home or known as work from home. This requirement is in accordance with the Circular of the Ministry of Education and Culture Number 4 of 2020 concerning about the implementation of Education Policies in the emergency period of the spread of the Corona virus. Since this distance learning model is a new thing for primary students, a principal must have programs that can maintain or improve the quality of education in the school he leads. One of them is supervision program. A program that aims to provide assistance to teachers to improve their quality. This supervision activity itself is a form of assistance from the principal to teachers who are still unable to work professionally. So with academic supervision, it is expected that it can help teachers in the learning process in the classroom, starting from the preparation, implementation, to learning evaluation.

Based on a preliminary study conducted by researcher at Paramount Elementary School Palembang, information was obtained that the Principal had organized academic supervision activities to improve the quality of teachers' abilities in the learning process during the early days of the Pandemic even though the implementation was still not optimal, as a result of the tight work agenda, especially related with administrative work. This administrative work is not only related to school administration but also financial 
and tax reports that must be done by the school principal herself. So that the principal's duties as a supervisor cannot be carried out optimally. As stated by [1] that the supervisor has a role as a : (1) coordinator, (2) consultant, (3) group leader, and (4) evaluator. The role of the principal as a supervisor at SD Paramount has not been maximized can be seen from the complaints and also suggestions received from parents of students. They complain because they are affected by the distance learning model or online indirectly. They complained about the implementation of learning in the early days of the pandemic which was considered ineffective for their children and tended to decline in quality. This phenomenon occurs because the teachers are still adapting to the application of distance learning or online models. Seeing the above phenomenon, it is clear why academic supervision must be carried out as an effort to carry out supervision and guidance in order to improve teacher quality on an ongoing basis. Therefore the Principal of SD Paramount Palembang as the supervisor immediately followed up on the complaints and suggestions from parents regarding the learning process in online learning. And then learning from previous experiences at the beginning of the pandemic the principal hold an academic supervision activities with adjustments in their implementation and strategies. By adjusting and applying an effective and efficient strategies, it is expected that the teachers are assisted in carrying out their duties and obligations and can manage the problems in the distance learning model learning process during the pandemic. In addition, the implementation of academic supervision is also expected to maintain and even improve the professional competence of teachers at SD Paramount. Related to the above background, the researcher is interested in conducting a study on academic supervision in improving the professional competence of teachers at SD Paramount Palembang.

\section{Method}

This research was conducted by using a qualitative approach method. [2] states that qualitative research is the collection of natural data, using natural methods, and is carried out by the researchers that are naturally interested in it. Data collection techniques are through 1) observation, namely direct observation at the place and object being observed 2) in-depth interviews, namely direct interviews with several respondents focused on knowing academic supervision activities and learning activities 3 ) documentation, namely collecting physical data such as documentation of the results of the principal's academic supervision in the form of assessments based on academic supervision instruments, photos of academic supervision activities, educational interaction activities carried out by teachers and students; and 4) literature study, which is the process of collecting data from articles from reputable journals and having scientific standards in terms of methodology and having extensive studies related to this research. The data analysis technique used in this study is qualitative data analysis, [3] suggest that activities in qualitative data analysis are carried out interactively and take place continuously at each stage of the research so that it is complete, and the data is saturated. . Activities in data analysis, namely data reduction, display data, and conclusion drawing / verification. According to [3] testing the credibility of research data will be carried out by: 1 . Extension of observation 2 . Increase persistence 3 . Triangulation 4. Member check (checking members). Data analysis techniques used in this study include data reduction, data presentation

\section{Results and Discussions}

As the implementation of academic supervision carried out by Paramount Palembang Elementary School for teachers related to professional competence in the form of supervision of the previous learning process, in the academic year 2020-2021 the Principal of Paramount Palembang Elementary School conducted supervision activities for teachers with adjustments to the situation and the current ongoing pandemic conditions.

From the findings in the field, it is known that in connection with the implementation of learning carried out remotely or online, the implementation of this supervision is also carried out online through the zoom media. Rather than that before carrying out supervision activities, the principal is assisted by a team deemed competent to help formulate a supervision program to create a supervision program that includes an annual program and a semester program at the beginning of each academic year with adjustments. The formulation of the supervision schedule prepared by the principal and the team based on the schedule and teaching hours as well as the school's academic calendar. This is so that teachers can prepare themselves well. In addition, the principal also especially formulates and prepares an instrument for the implementation of supervision which consists of 4 instruments, namely: 1) an instrument for administrative assessment of learning devices; 2) RPP assessment instrument; 3) learning implementation assessment instruments; 4) learning evaluation assessment instrument; and instrument 5 for follow-up. Then from the results of the field findings it can also be seen that the focus of supervision by the Principal who was assisted by the Team of Paramount School Palembang elementary school teachers, among others: 


\section{Academic Supervision in making Lesson Plan}

In this process the principal checks the completeness of the lesson plan document, starting from the preparation and making of the lesson plan document by the teacher to ensure whether everything, especially the teaching materials or materials to be delivered to students, is in accordance with the available time allocation, the formulation of material is clear (no ambiguous or multiple interpretations and containing the behavior of learning outcomes), selection of continuous teaching materials or materials (material systematics and conformity with predetermined time allocations), learning resources / media in accordance with the objectives, material and characteristics of students, the steps of learning activities : starting from the beginning, core and closing, the suitability of the technique with the learning objectives, and the completeness of learning instruments (questions, answer keys, guidelines in scoring or assessment) have been met

\section{Academic Supervision in Learning Implementation}

In this process the Principal who is assisted by the Team, also carries out academic supervision of the learning implementation process to ascertain whether the three stages in the implementation of learning, the pre-instructional, the instructional, and the evaluation stage. The principal and the team ensure whether the teacher has checked the readiness of students, and conducts apperception activities at the pre-instructional stage. Then at the instructional stage, ensure that the teacher shows mastery of the learning material, and connects the material discussed with other relevant knowledge, delivers the material clearly and in accordance with the learning sequence, connects learning material with the realities of life carrying out learning in accordance with the targets to be achieved, carry out continuous learning, master classroom conditions, carry out learning that fosters positive habits with planned time allocations, uses learning media effectively and efficiently, produces interesting moral messages, engages students in media use, fosters active participation of students in the learning process, showing openness to student reactions, fostering and increasing the love and enthusiasm of students during the learning process, observing the learning progress of students, using spoken and written language clearly, well and correctly, and conveying messages appropriately to classroom conditions. And the last is the evaluation and follow-up stage, whether the teacher observes the progress of learning during the learning process, carries out final assessments according to the competency of objectives, reflects or creates and compiles summaries by involving students, and carries out follow-ups by providing guidance and direction, or activities, or assignment as part of enrichment

\section{Academic Supervision in Learning Evaluation}

The Principal of SD Paramount Palembang supervises the evaluation of learning which includes: summative evaluation, formative evaluation, evaluation reports, improvement and enrichment programs. Formative evaluation is carried out by carrying out daily tests after the learning process is carried out. Then summative evaluation is carried out by providing exam questions from the material that has been submitted for six months / each semester. Finally, the evaluation report is given after carrying out daily tests and final tests of the semester. Meanwhile, the improvement and enrichment program is carried out if the daily test scores and semester-end tests have not reached the minimum completeness criteria. And the improvement and enrichment program is carried out by the teacher concerned.

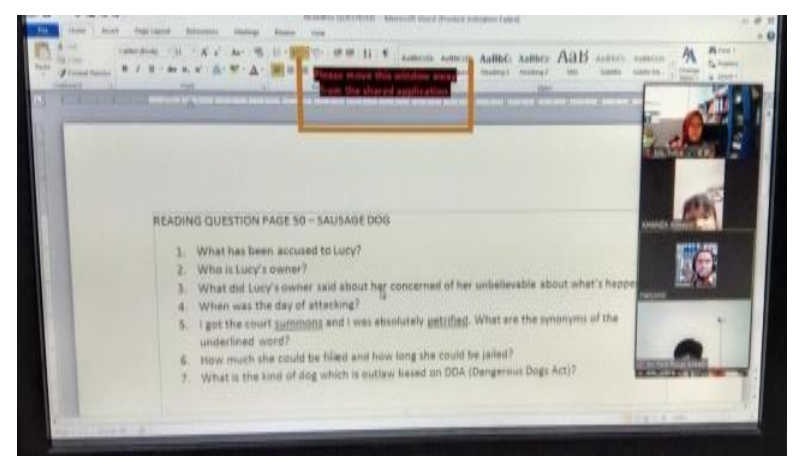

Figure 1. Online supervision implementation picture 


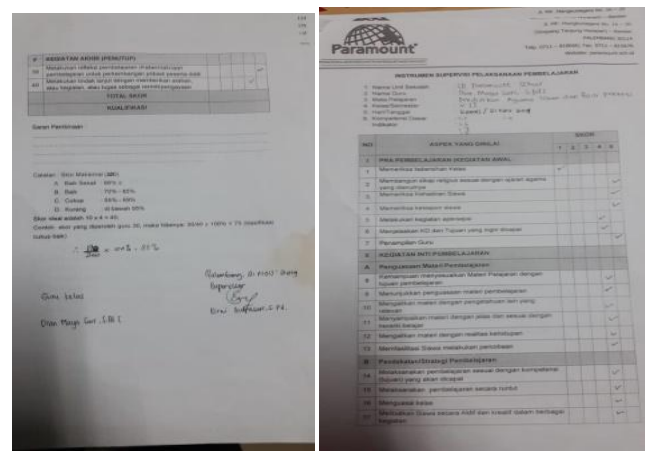

Figure 2. Learning implementation supervision document Pictures

Furthermore, The Principal of Paramount School Palembang applied the strategy to improve teacher professional competence. In the findings of this study, there are some strategies carried out by the Principal of Paramount School Palembang to improve teacher professional competence, including:

Increasing the professional competence of teachers in planning lessons through dialogue or sharing with the teacher concerned.

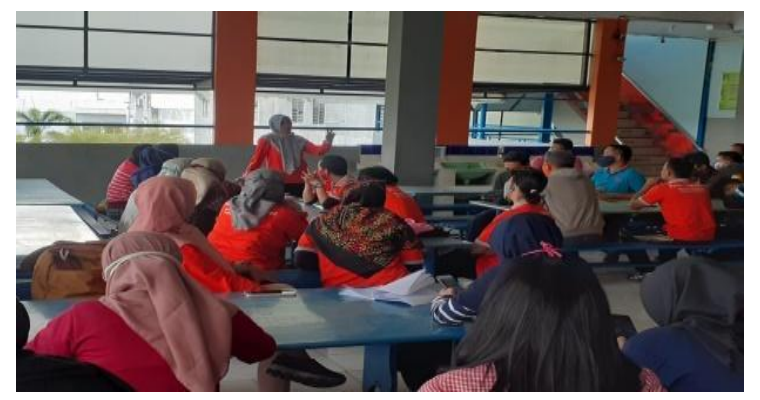

Figure 3. Dialogue between principal and teachers Picture

Increasing the professional competence of teachers in the implementation of learning by making observations with fellow teachers in the learning process and discussing the results of observations and providing input or input, as well as motivation about the importance of always improving the quality of learning, developing knowledge and utilizing existing technology.

Increasing teacher professional competence in learning evaluation by attending trainings.

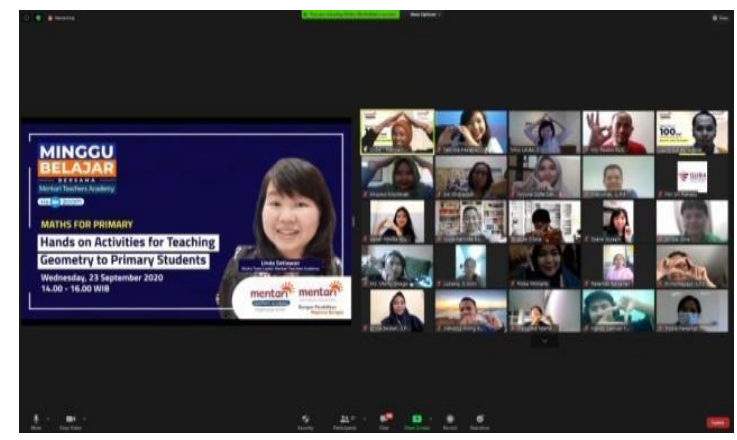

Figure 4. Online training images

After the supervision activities were carried out, the principal followed up on the results of these activities. [4] state that there are several steps in the follow-up to the results of academic supervision, including: 1) Review the summary of the supervision results. 2)Review the knowledge, skills and attitudes of teachers, 3) Designing a teacher academic supervision program for the next period4. Creating an academic supervision plan5. Implement the supervision plan for the next period.

From the findings in the follow-up field the results of the academic supervision of the Principal of Paramount School Palembang are as follows: a )Provide opinions and suggestions on learning planning 
documents and learning evaluation. that has been compiled or made, at the same time showing and providing examples of RPP (Learning Program Plan), learning methods, and good learning evaluations according to predetermined standards $b$ )If the learning planning document that has been made or compiled is deemed inadequate, the teacher in question will be asked to make improvements accompanied by knowledge and instructions on how to make a good learning planning document. c) Involving teachers in training or in house training on making learning planning documents, implementing learning, and making learning evaluations. $\backslash$

From the description above, it can be seen that the academic supervision of school principals can improve teacher professional competence even in conditions of a pandemic.

\section{Conclusion}

The focus of academic supervision by the Principal of the Paramount School Palembang Elementary School includes planning, implementing, and evaluating learning. Furthermore, the strategies implemented by the Principal of Paramount School Palembang in improving the professional competence of Paramount School Palembang elementary school teachers include: (a) conducting class visits ; (b) make observations or observations; (c) hold meetings and meetings; (d) providing training and training; and (e) one-on-one meetings with teachers. and follow-up of the principal's academic supervision on the professional competence of elementary school teachers at Paramount School Palembang. The follow-up actions taken by the Principal after the implementation of academic supervision of teachers at Paramount School Palembang Elementary School included: (a) conveying opinions on planned learning planning documents, implementing learning, making learning evaluations; (b) if the learning planning document prepared and prepared is not according to standards, the teacher is asked to make improvements; (c) The Principal of the Paramount School Palembang Elementary School facilitates and encourages teachers to take part in training on making lesson plans, implementing the teaching and learning process, and making learning evaluations. So it can be shown that academic supervision by the principal can maintain and improve the professional competence of teachers in this pandemic.

\section{References}

Sahertian, P. A. Basic Concepts and Educational Supervision Techniques in the Framework of Human Resource Development. Jakarta: Rineka Cipta. 2000

Moleong, L. Qualitative Research Methodology. Bandung: PT. Rosdakarya youth.2010

Sugiyono.. Educational Research Methods, Quantitative Approaches, Qualitative, and R\&D. Bandung: Alfabeta. 2013

Prasojo, L. D. and Sudiyono. Education Supervision. Yogyakarta: Gava Media. 2011 